\title{
PENERAPAN VIDEO PEMBELAJARAN UNTUK MENINGKATKAN HASIL BELAJAR SISWA KELAS IV DI SD MUHAMMADIYAH 3 SURABAYA PADA MASA PANDEMI COVID-19
}

\author{
Yuliyana ${ }^{1}$, Kunti Dian Ayu Afiani ${ }^{2}$, Ishmatun Naila ${ }^{3}$, \\ 1 Universitas Muhammadiyah Surabaya, \\ Email:yuliyana-2020@fkip.um-surabaya.ac.id \\ 2Universitas Muhammadiyah Surabaya, \\ Email:kuntidianayu@fkip.um-surabaya.ac.id \\ 3Universitas Muhammadiyah Surabaya, \\ Email: ishmatun@fkip.um-surabaya.ac.id
}

\begin{abstract}
Abstrak
Penelitian ini bertujuan untuk meningkatkan hasil belajar siswa dalam pembelajaran tematik dengan menerapkan video pembelajaran. Jenis penelitian ini adalah penelitian tindakan kelas. Subjek penelitian yaitu siswa kelas IV.B SD Muhammadiyah 3 Kota Surabaya semester ganjil pada tahun pelajaran 2021/2022 dengan jumlah 25 siswa. Instrument yang digunakan adalah form tes hasil belajar, tes keaktivan siswa dan tes pengelolaan guru dalam pembelajaran. Berdasarkan hasil penelitian peningkatan hasil belajar dengan persentase ketuntasan belajar klasikal siklus I dan siklus II yaitu $60 \%$ dan $88 \%$. Hasil observasi aktivitas siswa diperoleh peningkatan persentase rata-rata siklus I dan siklus II yaitu $70 \%$ dan $75 \%$. Hasil observasi pengelolaan guru dalam pembelajaran terdapat peningkatan persentase rata-rata siklus I dan siklus II yaitu $71 \%$ dan $78 \%$. Dari hasil penelitian ini dapat disimpulkan bahwa video pembelajaran dapat meningkatkan hasil belajar siswa.
\end{abstract}

Kata kunci: Video Pembelajaran, Hasil Belajar Siswa

\begin{abstract}
This study aims to improve student learning outcomes in thematic learning by applying learning videos. The research subjects were the students of class IV.B SD Muhammadiyah 3 Surabaya City from odd semester in academic year of 2021/2022 with a total 25 students. The instrument used was the form of learning outcomes test, student activity test and teacher management test in learning. Based on the results of the study, the increase in learning outcomes with the percentage of classical learning completeness in cycle I and cycle II were $60 \%$ and $88 \%$, respectively. The results of observing student activities obtained and increase in the average percentage of cycle I dan cycle II was around $70 \%$ and $75 \%$. The results from observations of teacher management in learning is increase in the average percentage of cycle I and cycle II were $71 \%$ and $78 \%$, respectively. From the results of this study, it can be concluded that learning videos can improve student learning outcomes.
\end{abstract}

Keywords : Learning Videos, Student Learning Outcome

\section{Pendahuluan}

Di seluruh dunia pada masa ini

yang belum teridentifikasi. Menurut Lembaga (WHO, 2022) gejala yang terdampak oleh wabah Covid-19. dialami pada seseorang yang terinfeksi Coronavirus Diseases 2019 (COVID-19) Covid-19 adalah gangguan berat antara adalah infeksi virus baru pada manusia lain seperti demam, batuk dan sesak 
napas bahkan sampai berujung pada kematian.

Menurut (Pendidikan et al., 2020) Surat Keputusan dari Kepala BNPB Nomor 9.A tahun 2020 tentang Penetapan Status Keadaan Tertentu Darurat Bencana Wabah Penyakit akibat Virus Corona di Indonesia. Pemerintah Indonesia melalui Kementerian Pendidikan dan Kebudayaan (Kemendikbud) mengeluarkan surat edaran nomor 4 tahun 2020 tentang pelaksanaan kebijakan pendidikan dalam masa darurat penyebaran COVID-19 serta mengeluarkan surat edaran nomor 15 tahun 2020 tentang pedoman penyelenggaraan belajar dari rumah dalam masa darurat penyebaran COVID19.

Sebagai upaya dalam mencegah penularan Covid-19 pada masa pandemi, Pemerintah mengeluarkan kebijakan untuk meliburkan siswa dan menerapkan metode belajar dengan sistem daring (dalam jaringan) atau online. Sistem pembelajaran daring (dalam jaringan) adalah solusi dalam situasi pandemi saat ini, dimana siswa tetap bisa belajar walaupun tidak secara tatap muka. Akan tetapi, dalam pelaksanaan pembelajaran daring pasti banyak terdapat kesulitan yang dihadapi baik oleh guru maupun siswa.
Menurut (Hidayat \& Sadewa, 2020)), banyak guru yang masih belum menguasai teknologi, terutama bagi yang tinggal di daerah pedalaman. Sedangkan Guru harus memperhatikan kegiatan belajar mengajar tetap terlaksana, meskipun siswa berada di rumah.

Namun, selama pembelajaran daring di SD Muhammadiyah 3 Surabaya terutama pada kelas 4 guru mengalami beberapa hambatan dan kesulitan selama melaksanakan pembelajaran, seperti guru kurang menguasai penggunaan teknologi dan guru hanya mengintruksikan tugas melalui aplikasi whatsapp group, dll.

Bagaimana siswa bisa menyelesaikan tugasnya, sedangkan materinya saja siswa belum memahami karena tidak ada interaksi antara guru dengan siswa. Hal tersebut dapat membuat hasil belajar siswa menjadi rendah, apabila guru memberikan evaluasi belajar.

Hal tersebut terbukti dari hasil Penilaian Harian Online pada Tema 1 tahun pelajaran 2021/2022, dimana menunjukkan bahwa nilai rata-rata yang diperoleh setiap siswa kelas IV belum mencapai nilai di atas Kriteria Ketuntasan Minimal (KKM) yang ditetapkan sekolah yaitu $\geq 80$. Hasil PH (Penilian Harian) Tema 1 Tahun Pelajaran 2021/2022 pada mata 
pelajaran tematik mendapat nilai ratarata 67,88 .

Berdasarkan nilai rata-rata tersebut dapat dikatakan bahwa hasil belajar siswa kelas IV-B SD Muhammadiyah 3 Surabaya tergolong rendah, karena tidak mencapai nilai Kriteria Ketuntasan Minimal (KKM) yang ditetapkan sekolah yaitu $\geq 80$. Salah satu cara yang dapat dilakukan untuk meningkatkan hasil belajar dan keaktifan siswa yaitu peran guru dalam memanfaatkan teknologi pembelajaran berupa video sebagai media pembelajaran di kelas daring.

Berdasarkan permasalahan di atas, adapun rumusan masalah dalam penelitian ini yaitu Bagaimana meningkatkan hasil belajar siswa kelas IV di SD Muhammadiyah 3 Surabaya melalui penerapan video pembelajaran pada masa pandemi covid-19? Bagaimana aktifitas siswa selama pembelajaran daring? Bagaimana guru dalam pengelolaan pembelajaran?

Guru diminta untuk dapat merancang media pembelajaran dalam jaringan (daring) yang mudah, ringan dan juga efektif, dengan memanfaatkan perangkat pembelajaran atau media pembelajaran daring yang menarik dan sesuai dengan materi dan tujuan pembelajaran yang diajarkan. Guru harus dapat memilih dan membatasi sejauh mana materi dan aplikasi yang digunakan sesuai, sebagai inovasi dengan memanfaatkan media internet.

Menurut (Afiani, K. D. A., \& Putra, D. A., 2017) pembelajaran yang kreatif dan inovatif yang berpusat pada siswa adalah kewajiban guru. Menurut (Efendi Pohan, 2020) menyatakan bahwa pembelajaran adalah segala sesuatu yang dapat membawa pengetahuan dan informasi kedalam interaksi yang berlangsung antara guru dan siswa.

Pembelajaran daring dapat menggunakan bermacam-macam platform aplikasi seperti: WhatApp group, zoom meeting, google meet, Ms. Teams, google classroom, dll. Aplikasi tersebut digunakan untuk memudahkan pemberian intruksi tugas yang harus dikerjakan oleh siswa.

Menurut (Afiani, K., \& Faradita, M., 2021) jika ingin mendapatkan hasil belajar yang ideal, maka dibutuhkan media pembelajaran yang mendukung dalam proses pembelajaran supaya bisa berlangsung dengan baik. Selain itu, siswa dapat memahami materi yang disampaikan oleh guru. Dari pernyataan tersebut, maka dibutuhkan sebuah media pembelajaran yang dapat digunakan untuk menunjang keberhasilan proses pembelajaran selama daring.

Hal utama yang sulit dalam menentukan rancangan suatu 
pembelajaran adalah menentukan medium atau media yang bisa digunakan untuk menyampaikan pembelajaran (Dick, W and Carrey, 1985) Media pembelajaran yang diharapkan adalah penyajian materi lebih jelas disertai dengan adanya contoh yang menarik berupa fakta, foto atau gambar, data, grafik, dengan suara. Sehingga dapat menjadikan suatu kegiatan belajar mengajar menjadi lebih inovatif dan menarik meskipun dalam jaringan internet.

Dalam

memilih

media pembelajaran yang sesuai di masa pandemi Covid-19 adalah suatu hal yang sangat penting untuk dipertimbangkan oleh guru. Supaya siswa terbantu untuk dapat memahami materi pelajaran yang disampaikan, walaupun siswa belajar dari rumah masing-masing.

Menurut (Susmiati, 2020) Media video pembelajaran dianggap cocok bila digunakan pada masa pandemi Covid19, karena sangat mudah digunakan dan bisa diikuti oleh seluruh siswa di rumah. Menurut (Zainuddin Atsani, 2020) Selain itu selama pandemi, guru tidak dapat tatap muka dengan siswa secara langsung, dengan adanya media video pembelajaran ini dapat memudahkan guru memberikan penjelasan materi pembelajaran.
Temuan dari (Hasler et al., 2007) menunjukkan bahwa hanya kemungkinan untuk mengontrol aliran informasi sementara dalam animasi dengan tombol stop and play sama bermanfaatnya untuk pembelajaran dengan membuat peserta didik belajar dengan animasi yang dibagi menjadi segmen yang telah ditentukan, bahkan jika fitur masing-masing hampir tidak digunakan. Menariknya, memberikan peserta didik kemungkinan untuk mengubah urutan informasi menyebabkan hasil belajar yang lebih baik, meskipun kemungkinan untuk mengubah urutan juga hampir tidak digunakan (Wouters et al., 2010). Dengan demikian, memberikan kesempatan kepada peserta didik untuk mengontrol kecepatan informasi secara interaktif kapan pun mereka merasa perlu, mungkin merupakan pendekatan yang menjanjikan untuk meningkatkan potensi video sebagai alat pembelajaran.

Tujuan dari menggunakan media video pembelajaran ini adalah memberikan penjelasan materi yang menarik sesuai dengan pengetahuan yang disampaikan guru pada siswa dan penyampaian informasi sesuai dengan tujuan pembelajaran yang diharapkan. Media video pembelajaran merupakan media yang menunjukkan unsur visual (penglihatan) dan auditif (pendengaran) 
sehingga dapat dipandang dan juga bisa didengarkan suaranya (Anitah, 2010).

Media video adalah alat yang bisa digunakan oleh siswa merangsang keinginan, pikiran serta perasaan dengan menyampaikan pesan, ide dan gagasan serta informasi secara audio visual (Wisada et al., 2019)

Media video pembelajaran dianggap bisa mengatasi kejenuhan dan kebosanan siswa belajar dirumah (Hadi, 2017)

Menggunakan media video ini bisa merangsang siswa untuk termotivasi belajar karena ada rasa keingintahuan siswa akan video yang ditampilkan. Oleh karena itu, bisa meningkatkan pemahaman materi yang diberikan guru (Kirana, 2016)

Media video dapat dimanfaatkan untuk pembelajaran pada kurikulum 2013 dalam pembelajaran tematik. Oleh sebab itu, dilihat dari banyaknya manfaat yang diperoleh dari menggunakan media video pembelajaran ini dalam masa pandemi Covid-19, maka guru dapat mengaplikasikan media video pembelajaran ini ke dalam kegiatan pembelajarannya.

Penelitian ini melihat sejauh mana pelaksanaan media video pembelajaran dilaksanakan di sekolah dasar selama masa pandemi Covid-19 berdasarkan perspektif guru. Sehingga tujuan dari penelitian ini adalah; (1) Mengetahui peningkatkan hasil belajar siswa kelas 4B di SD Muhammadiyah 3 Surabaya pada masa pandemi covid-19 dengan menerapkan video pembelajaran. (2) Untuk mengetahui peningkatan hasil observasi keaktifan siswa (3) Untuk mengetahui hasil observasi pengelolaan guru dalam pembelajaran daring.

\section{Metode Penelitian}

Metode penelitian yang digunakan dalam penelitian ini adalah Penelitian Tindakan Kelas (PTK). Peneliti mengambil desain model penelitian tindakan spiral dari Kurt Lewin dalam (Iskandar et al., 2015) yang memiliki prosedur penelitian satu siklus PTK yang terdiri dari empat langkah sebagai berikut: (1) Perencanaan, yaitu membuat skenario pembelajaran, membuat lembar observasi dan mendesain alat evaluasi.

Pelaksanaan, yaitu melaksanakan pembelajaran yang telah dibuat. (3) Pengamatan, yaitu kegiatan ini adalah realisasi dari lembar observasi yang sudah dibuat pada tahap perencanaan. (4) Refleksi, yaitu kegiatan yang sudah dilakukan oleh guru maupun siswa, menurut (Arikunto S., 2006) dalam (Iskandar et al., 2015)

Penelitian ini dilaksanakan di SD Muhammadiyah 3 kota Surabaya dengan 67 | Penerapan Video Pembelajaran untuk Meningkatkan Hasil Belajar......... 
subjek kelas IV.B dengan jumlah 26 siswa terdiri dari 15 siswa laki-laki dan 11 siswa perempuan. Waktu penelitian yang digunakan yaitu pada semester I tahun pelajaran 2021/2022. Materi yang diambil saat penelitian dilakukan adalah Tema 1 Subtema 2.

Instrumen penelitian ini berbentuk tes dan non tes yang akan memperoleh data kualitatif dan kuantitatif. Untuk mengetahui kemampuan kognitif siswa, instrumen tes yang digunakan adalah evaluasi hasil belajar siswa berbentuk tes soal pilihan ganda yang akan menghasilkan data kuantitatif, sedangkan untuk mengetahui tingkat keaktifan siswa dalam proses pembelajaran dan mengetahui kegiatan guru dalam mengelola pembelajaran, akan menggunakan instrumen non tes berupa lembar observasi aktivitas siswa dan lembar observasi kegiatan guru dalam mengelola pembelajaran. Untuk menghitung data kualitatif dan kuantitatif dapat menggunakan skala Likert.

Teknik analisis data yang digunakan pada waktu penelitian tindakan kelas ini antara lain yaitu penskoran pada hasil lembar jawaban siswa pada tema 1 subtema 2 dengan menggunakan media video pembelajaran dan aktivitas guru dan siswa pada saat pembelajaran daring berlangsung.

68 | Autentik: Jurnal Pengembangan Pendidikan Dasar, Vol. 6, No. 1, Februari 2022 data yang diperoleh melalui hasil tes dan observasi yang akan dilakukan, analisis data yang diperoleh dijabarkan sebagai berikut:

\section{Teknik Analisis Data Observasi}

a. Teknik Analisis Data Observasi Aktivitas Siswa.

Menghitung prosentase rata-rata dari setiap kriteria untuk tiap-tiap aktivitas siswa dalam pembelajaran. Rumus yang digunakan yaitu:

$$
\begin{aligned}
& \text { Persentase Keaktifan } \% \\
& =\frac{\text { Skor maksimal }}{\text { Skor Total }} \times 100 \%
\end{aligned}
$$

Menurut (Uno, 2011) bahwa aktivitas siswa dikatakan aktif dalam pembelajaran, jika persentase rata-rata dari aktivitas siswa yang aktif mencapai $\geq 75$.

\section{b. Teknik Analisis Data Observasi Aktivitas Guru dalam Mengelola Pembelajaran.}

Skala penilaian aktivitas guru dalam mengelola pembelajaran dibuat dari rentang 1 sampai 4 dengan ketentuan sebagai berikut: 
Tabel 1. Kriteria skor penilaian

\begin{tabular}{|c|c|c|}
\hline $\begin{array}{c}\text { Skor } \\
\text { Penilaian }\end{array}$ & Kriteria & Deskripsi \\
\hline 4 & Sangat baik & $\begin{array}{c}\text { Dilakukan dengan sangat baik oleh } \\
\text { guru, pembelajaran sempurna dan } \\
\text { guru terlihat professional }\end{array}$ \\
\hline 3 & Baik & $\begin{array}{c}\text { Pembelajaran dilaksanakan dengan } \\
\text { baik oleh guru, pembelajaran tanpa } \\
\text { kesalahan dan guru terlihat menguasai }\end{array}$ \\
\hline 2 & Cukup & $\begin{array}{c}\text { Dilaksanakan dengan cukup baik oleh } \\
\text { guru, pembelajaran dengan sedikit } \\
\text { kesalahan dan guru sudah cukup } \\
\text { menguasai }\end{array}$ \\
\hline 1 & Kurang & $\begin{array}{c}\text { Tidak dilaksanakan oleh guru, } \\
\text { Pembelajaran terdapat banyak } \\
\text { kesalahan, guru terlihat tidak } \\
\text { menguasai }\end{array}$ \\
\hline & & \\
\hline
\end{tabular}

(Purwanti \& Dkk, 2008)

Data yang telah diperoleh yang diamati setiap kali pertemuan. Nilai dianalisis dengan cara menghitung nilai rata-rata tersebut selanjutnya rata-rata keseluruhan aspek kemampuan dikonversikan dengan skala sebagai guru dalam mengelola pembelajaran berikut:

Tabel 2. Skala Penilaian Kategori Kemampuan Guru

\begin{tabular}{|c|c|}
\hline Skala & Kriteria \\
\hline $85-100$ & Sangat Baik \\
\hline $70-84$ & Baik \\
\hline $55-69$ & Cukup Baik \\
\hline $40-54$ & Kurang \\
\hline
\end{tabular}

(Hamalik, 1989)

Berdasarkan tabel diatas, Nilai

kemampuan guru dalam mengelola $=\frac{\text { Jumlah skor yang diperoleh tiap pertemuan }}{\text { Jumlah skormaksimal }} \times 100$ pembelajaran dikatakan efektif jika mencapai kriteria minimal baik. Rumus (Sudjana, 1989) aktivitas pengelolaan guru adalah sebagai berikut:

69 | Penerapan Video Pembelajaran untuk Meningkatkan Hasil Belajar. 


\section{Teknik Analisis Data Tes Hasil Belajar Siswa.}

Tes dilakukan untuk mengetahui ketuntasan siswa dalam memahami dan menguasai materi dan sejauh mana ketuntasan belajar siswa yang sesuai dengan $\mathrm{KI}$ dan $\mathrm{KD}$ serta tercapainya tujuan pembelajaran.

Berdasarkan Kriteria Ketuntasan Minimum (KKM) di SD Muhammadiyah 3 Surabaya, siswa dikatakan tuntas belajar jika mendapat nilai $\geq 80$, dengan ketuntasan klasikalnya sebesar $\geq 75 \%$.

Rumus mendapatkan nilai hasil belajar adalah

$$
N=\frac{\sum \text { Skor Perolehan }}{\text { Skor Maks. }} \times 100
$$

(Zainal, 2011)

Untuk mendapatkan persentase ketuntasan klasikal digunakan rumus sebagai berikut:

$$
P=\frac{\sum \text { siswa yang tuntas }}{\sum \text { seluruh siswa }} \times 100 \%
$$

\section{Hasil dan Pembahasan}

Penelitian Tindakan Kelas ini dilaksanakan dalam 2 siklus yaitu siklus I pada tanggal 1-2 Desember 2021 dan siklus II pada tanggal 8 - 9 Desember 2021 masing-masing siklus ada 2 kali pertemuan. Penelitian dilaksanakan secara daring yaitu siswa berada dirumah masing-masing. Pembelajaran dilakukan dengan menggunakan media video pembelajaran yang di share screen pada platform Zoom Meeting.

Kegiatan yang dilakukan adalah guru membuka pelajaran melalui Zoom Meeting dengan salam dan menanyakan kesiapan siswa untuk mengikuti pembelajaran, menyampaikan materi yang akan dipelajari, memotivasi siswa dan mengecek daftar hadir siswa.

Setelah itu meminta siswa untuk mengamati dan menyimak video pembelajaran yang sudah di tayangkan pada layar. Kemudian guru mengidentifikasi materi yang belum dimengerti dan memberi kesempatan untuk siswa bertanya dan berdiskusi bersama dengan teman yang lainnya. Guru mengirimkan link google form Lembar Tes Hasil Belajar Siswa https://forms.gle/S4g7VQuo9AP2XPwx7 melalui Whatsapp grup yang harus dikerjakan siswa sesuai dengan waktu yang telah ditentukan.

Selanjutnya guru beserta siswa membuat kesimpulan dari pembelajaran yang berlangsung hari ini, guru memberikan motivasi siswa agar rajin belajar dan menutup pembelajaran dengan doa bersama dan salam.

Data hasil belajar pada siklus I dan II diperoleh dari tes melalui link google form https://forms.gle/S4g7VQuo9AP2XPwx7 
secara individual yang dilaksanakan berakhir. Data hasil belajar siklus I di setelah kegiatan pembelajaran daring sajikan dalam bentuk grafik berikut ini:

\section{Grafik 1. Nilai Hasil Belajar Siswa Pada Siklus I}

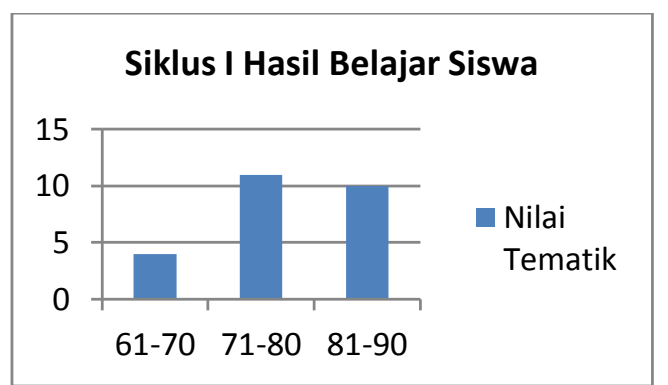

Berdasarkan grafik 1 di atas dan kuesioner diisi oleh guru wali kelas 6B, nilai KKM di SD Muhammadiyah 3 guru wali kelas 4B guru wali kelas 4C Surabaya sebesar $\geq 80$, maka nilai hasil sebagai observer. Berikut adalah belajar pada siklus I menunjukkan jumlah pembahasan hasil dari data yang di siswa kelas IV-B pada tema 1 subtema 2 dapat oleh peneliti.

yang tuntas sebanyak 10 siswa dan yang Pembelajaran di SD belum tuntas sebanyak 15 siswa Muhammadiyah 3 Surabaya pada masa dengan nilai rata sebesar 76,84 . Oleh pandemi covid-19 dilakukan secara karena itu diperoleh persentase daring. Guru memberikan pembelajaran ketuntasan klasikal pada siklus I sebesar melalui platform Zoom Meeting. Melalui $60 \%$. Dengan demikian pada siklus I Zoom Meeting guru dapat memantau dikatakan belum tuntas karena segala aktivitas siswa selama persentase ketuntasan klasikal kurang pembelajaran daring berlangsung. dari $75 \%$. Berdasarkan hasil observasi yang

Analisis aktivitas siswa selama peneliti lakukan saat pembelajaran pembelajaran daring di kelas IV-B SD berlangsung dari 25 siswa yang hadir Muhammadiyah 3 Surabaya pada masa ketika pembelajaran. Beberapa indikator pandemi covid-19. Data berupa pada pedoman observasi yang peneliti observasi pada saat pembelajaran buat maka dapat dijabarkan pada tabel daring berlangsung dan angket atau berikut: 


\section{Grafik 2. Hasil Observasi Keaktifan Siswa Selama Pembelajaran Daring pada Siklus I}

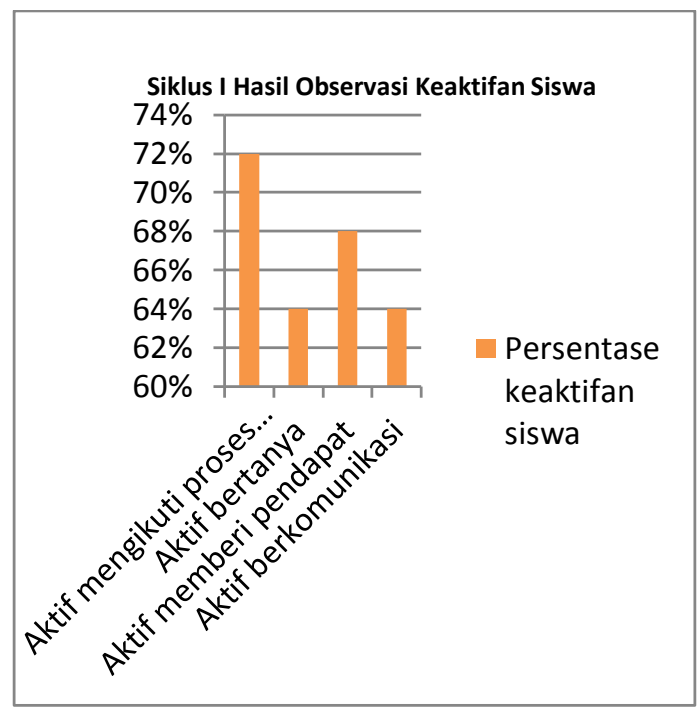

Berdasarkan grafik diatas mengacu dilakukan sesuai dengan rencana pada indikator keberhasilan maka dapat pembelajaran yang telah disusun oleh disimpulkan bahwa keaktifan siswa guru dalam skenario pembelajaran. selama pembelajaran daring Selama pelaksanaan kegiatan mendapatkan nilai persentase rata-rata berlangsung, proses pembelajaran sebesar $70 \%$ siswa tersebut dikatakan diamati oleh dua orang observer, yang belum aktif. Karena siswa dikatakan bertindak sebagai observer yaitu teman aktif, apabila siswa memperoleh nilai sejawat wali kelas 4C dan wali kelas 6B. persentase rata-rata sebesar $75 \%$. Observasi ini dilakukan guna mengetahui

Analisis data berikutnya pada sejauh mana aktivitas guru dalam penelitian ini adalah observasi aktivitas mengelola pembelajaran daring. Dari guru dalam mengelola pembelajaran hasil observasi aktivitas guru dapat daring. Pelaksanaan pembelajaran dilihat melalui tabel berikut:

Tabel 3. Hasil Observasi Aktivitas Guru dalam Mengelola Pembelajaran Daring

\begin{tabular}{|c|c|c|c|c|c|c|}
\hline No & Pengamat & $\begin{array}{c}\text { Skor } \\
\text { total }\end{array}$ & \multicolumn{4}{|c|}{$\begin{array}{c}\text { Kriteria } \\
\text { Penilaian }\end{array}$} \\
\cline { 4 - 7 } & & & S & B & C & K \\
& & & B & & & \\
\hline 1 & 1 & $74 \%$ & & $\sqrt{ }$ & & \\
\hline 2 & 2 & $68 \%$ & & & $\sqrt{ }$ & \\
\hline \multicolumn{2}{|c|}{$\begin{array}{c}\text { Persentase Rata- } \\
\text { rata }\end{array}$} & $71 \%$ & & & \\
\hline
\end{tabular}


Hasil analisis aktivitas guru dalam mengelola pembelajaran daring mendapatkan persentase rata-rata $71 \%$ yang tergolong baik.

Dari beberapa penelitian yang telah di lakukan pada siklus I yaitu tes hasil belajar siswa, keaktifan siswa dan pengelolaan guru dalam pembelajaran masih ditemukan beberapa kelemahan yang perlu diperbaiki pada siklus II, antara lain:

1. Penyampaian informasi pada siswa masih kurang jelas.

2. Pemanfaatan waktu yang digunakan belum sesuai dengan skenario pembelajaran daring yang dirancang
3. Kondisi jaringan tidak stabil dan membutuhkan jaringan internet yang kuat

4. Penggunaan media video pembelajaran yang ditayangkan mengalami kendala sinyal pada beberapa siswa

5. Kurangnya pemberian penguatan pada siswa masih sedikit.

Perbaikan pembelajaran dilanjutkan pada siklus II yaitu data dari tes hasil belajar pada siklus II yang diikuti oleh 25 siswa melalui link google form dapat di sajikan dalam bentuk grafik berikut ini:

\section{Grafik 3. Nilai Hasil Belajar Siswa Pada Siklus II}

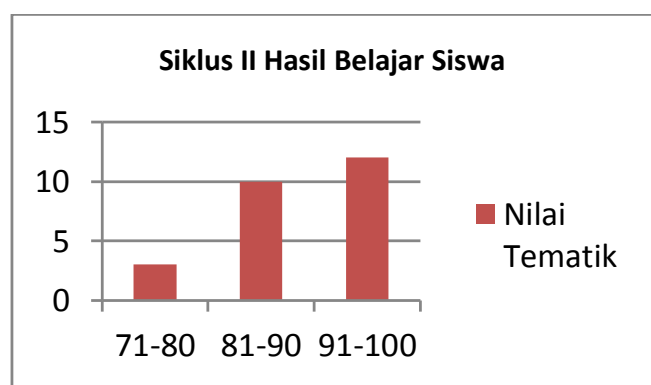

Berdasarkan grafik 2 di atas nilai Persentase ketuntasan klasikal pada hasil belajar pada siklus II menunjukkan siklus II sebesar $88 \%$. Dengan demikian, yang tuntas KKM sebanyak 17 siswa dan pada siklus II dikatakan tuntas karena yang belum tuntas sebanyak 8 siswa persentase ketuntasan klasikal $\geq 75 \%$. dengan nilai rata sebesar 86,68.

Tabel 4. Persentase dan Rata-rata Hasil Belajar Siswa pada Siklus I dan Siklus II

\begin{tabular}{|c|c|c|c|}
\hline Siklus & $\begin{array}{c}\text { Jml } \\
\text { Siswa }\end{array}$ & $\begin{array}{c}\text { Nilai Rata-rata } \\
\text { (KKM) }\end{array}$ & $\begin{array}{c}\text { Persentase ketuntasan } \\
\text { klasikal }\end{array}$ \\
\hline I & 25 & 76,84 & $60 \%$ \\
\hline II & 25 & 86,68 & $88 \%$ \\
\hline
\end{tabular}


Analisis aktivitas siswa selama hasil data sebagai berikut: pembelajaran pada siklus II diperoleh

\section{Grafik 4.Hasil Observasi Keaktifan Siswa Selama}

\section{Pembelajaran Daring pada Siklus II}

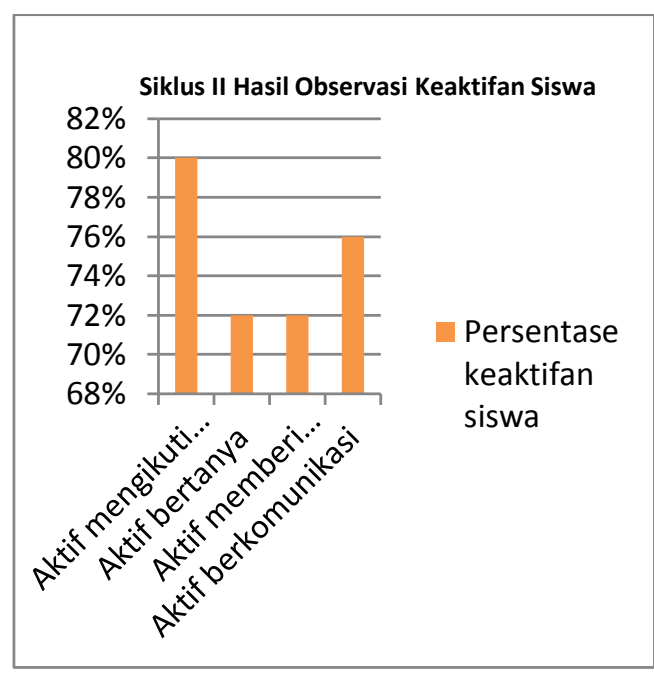

aktif. Karena memperoleh nilai

Berdasarkan grafik diatas dapat persentase rata-rata sebesar $75 \%$.

disimpulkan bahwa keaktifan siswa Analisis data pada siklus II berikutnya selama pembelajaran daring adalah observasi aktivitas guru dalam mendapatkan nilai persentase rata-rata mengelola pembelajaran daring. Dari sebesar $75 \%$ siswa tersebut dikatakan hasil observasi aktivitas guru dapat dilihat melalui tabel berikut:

Tabel 5. Hasil Observasi aktivitas Guru dalam Mengelola Pembelajaran Daring pada Siklus II

\begin{tabular}{|c|c|c|c|c|c|c|}
\hline No & Pengamat & $\begin{array}{c}\text { Skor } \\
\text { total }\end{array}$ & \multicolumn{4}{|c|}{$\begin{array}{c}\text { Kriteria } \\
\text { Penilaian }\end{array}$} \\
\cline { 4 - 7 } & & & SB & B & C & K \\
\hline 1 & 1 & $80 \%$ & & $\sqrt{ }$ & & \\
\hline 2 & 2 & $76 \%$ & & $\sqrt{ }$ & & \\
\hline \multicolumn{2}{|c|}{ Persentase Rata-rata } & $78 \%$ & \multicolumn{5}{|c|}{} \\
\hline
\end{tabular}

Hasil analisis aktivitas guru pada

Pembelajaran daring dengan siklus II dari tabel diatas, dalam menggunakan media video mengelola pembelajaran daring pembelajaran ini sangat baik, hal ini mendapatkan persentase rata-rata $78 \%$ ditunjukkan dengan adanya peningkatan yang tergolong baik. pada penelitian siklus II baik dari hasil belajar siswa, keaktifan siswa dan 
pengelolaan guru dalam pembelajaran

yang di sajikan dalam grafik berikut ini:

Grafik 5. Perbandingan Hasil Belajar, Observasi Aktifitas Siswa dan Guru pada Siklus I dan Siklus II

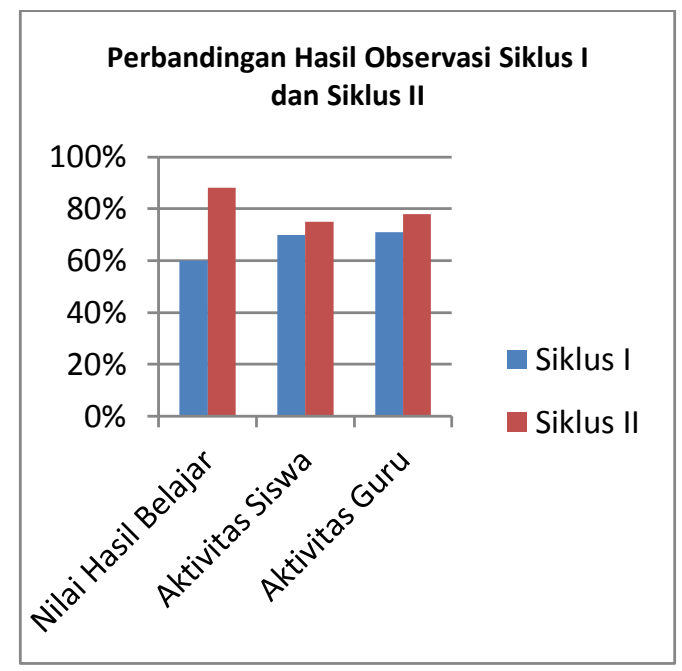

\section{Berdasarkan grafik 3 diatas KESIMPULAN}

adapun hasil yang diperoleh adalah

Penerapan video pembelajaran adanya peningkatan hasil dari yang dapat meningkatkan hasil belajar siswa sebelumnya pada siklus I nilai hasil terlihat dari hasil penelitian berikut: (1) belajar klasikal sebesar $60 \%$ meningkat Hasil belajar siswa secara klasikal menjadi $88 \%$ pada siklus II, sedangkan meningkat sebesar $28 \%$ dari siklus I pada aktifitas siswa pada siklus I sebesar $60 \%$ menjadi $88 \%$ pada siklus II. sebesar $70 \%$ meningkat menjadi $75 \%$ (2) Hasil observasi aktivitas siswa pada siklus II dan pengelolaan guru diperoleh peningkatan persentase ratadalam pembelajaran pada siklus I rata sebesar 5\% dari siklus I sebesar sebesar $71 \%$ meningkat menjadi $78 \% \quad 70 \%$ menjadi $75 \%$ pada siklus II dan (3) pada siklus II. Dari hasil tersebut maka Hasil observasi pengelolaan guru dalam penelitian ini dihentikan karena terdapat pembelajaran terdapat peningkatan peningkatan hasil data. persentase rata-rata dari siklus I sebesar $7 \%$ dari siklus I sebesar $71 \%$ menjadi $78 \%$ pada siklus II. 


\section{Daftar Pustaka}

Afiani, K. D. A., \& Putra, D. A. (2017, September). Pengajuan Masalah Sebagai Alternatif Menumbuhkan Kemampuan Berpikir Kreatif Siswa. In: Seminar Nasional Kearifan Lokal Bagi Peningkatan Kualitas Pendidikan Dasar,. Seminar Nasional Kearifan Lokal Bagi Peningkatan Kualitas Pendidikan Dasar,. http://repository.um-surabaya.ac.id/5317/

Afiani, K., \& Faradita, M. (2021). Analisis Aktivitas Siswa dalam Pembelajaran Daring Menggunakan Ms . Teams pada Masa Pandemi Covid-19. Jurnal Pemikiran Dan Pengembangan Sekolah Dasar, 9(1), 16-27. http://ejournal.umm.ac.id/index.php/jp2sd

Anitah, S. (2010). Media pembelajaran. Yuma Pressindo.

Arikunto S. (2006). Prosedur penelitian suatu pendekatan praktik. Jakarta: Rineka Cipta.

Dick, W and Carrey, L. (1985). The Systematic Design Instruction.

Efendi Pohan, A. (2020). KONSEP PEMBELAJARAN DARING BERBASIS PENDEKATAN ILMIAH - Albert Efendi Pohan, S. 236. https://books. google.co.id/books?id=s9bsDwAAQBAJ\&printsec=frontcover\&dq=k onsep+pembelajaran+daring+berbasis+pendekatan+ilmiah\&hl=id\&sa=X\&ved=2 ahUKEwjs8u7bx_HrAhVe7XMBHWDSDbIQ6AEwAHoECAEQAg\#v=onepage\&q $=$ konsep pembelajaran daring berbasis pendekatan ilmiah\&

Hadi, S. (2017). Efektivitas Penggunaan Video Sebagai Media Pembelajaran untuk Siswa Sekolah Dasar. Prosiding TEP \& PDs, 1(15), 96-102. https://core.ac.uk/download/pdf/267023793.pdf

Hamalik, O. (1989). Metodologi pengajaran ilmu pendidikan.

Hasler, B. S., Kersten, B., \& Sweller, J. (2007). Learner control, cognitive load and instructional animation. Applied Cognitive Psychology, 21(6), 713-729. https://doi.org/10.1002/acp.1345

Hidayat, A., \& Sadewa, P. (2020). Pengaruh Penggunaan Aplikasi Eviews Terhadap Sikap Belajar dan Kemampuan Pemecahan Masalah Statistik. Edumaspul: Jurnal Pendidikan, 4(1), 321-328. https://ummaspul.e-journal.id/

Iskandar, Dadang, \& Narsim. (2015). Penelitian Tindakan Kelas dan Publikasinya Untuk Kenaikan Pangkat dan Golongan Guru \& Pedoman Penulisan PTK bagi Mahasiswa. Ihya Media.

Kirana, M. (2016). the Use of Audio Visual To Improve Listening. English Education Journal (Program Pascasarjana Universitas Negeri Semarang), 7(2), 233-245.

Pendidikan, M., Kebudayaan, D., \& Indonesia, R. (2020). Pelaksanaan Kebijakan Pendidikan dalam Masa Darurat Penyebaran Coronavirus Disease(Covid-19). Surat Edaran Dari Kemetrian RI, 1-3.

76 | Autentik: Jurnal Pengembangan Pendidikan Dasar, Vol. 6, No. 1, Februari 2022 
Purwanti, E., \& Dkk. (2008). Assesmen Pembelajaran SD, Direktorat Jenderal.

Sudjana. (1989). Metode Statiska. In Metode Statiska. Tarsito Bandung.

Susmiati, E. (2020). Meningkatkan Motivasi Belajar Bahasa Indonesia Melalui Penerapan Model Discovery Learning dan Media Video Dalam Kondisi Pandemi Covid-19 bagi Siswa SMPN 2 Gangga. Jurnal Paedagogy, 7(3), 210. https://doi.org/10.33394/jp.v7i3.2732

Uno, H. B. (2011). Teori Motivasi dan Pengukurannya - Google Books. In Bumi Aksara. PT Bumi Aksara Bandung PT Remaja Rosdaka Karya. https://www.google.co.id/books/edition/Teori_Motivasi_dan_Pengukurannya/v_cr EAAAQBAJ?hl=en\&gbpv=1\&dq=Teori+motivasi+dan+Pengukurannya+(Analisis + di+Bidang+\%09Pendidikan)\&printsec=frontcover

WHO. (2022). Coronavirus Disease. Coronavirus Disease. https://doi.org/10.1016/c2020-0-01739-1

Wisada, P. D., Sudarma, I. K., \& Yuda S, A. I. W. I. (2019). Pengembangan Media Video Pembelajaran Berorientasi Pendidikan Karakter. Journal of Education Technology, 3(3), 140. https://doi.org/10.23887/jet.v3i3.21735

Wouters, P., Paas, F., \& van Merriënboer, J. J. G. (2010). Observational learning from animated models: Effects of studying-practicing alternation and illusion of control on transfer. Instructional Science, 38(1), 89-104. https://doi.org/10.1007/s11251-008-9079-0

Zainal, A. (2011). Penelitian Tindakan Kelas untuk Guru SMP, SMA, SMK. Penelitian Tindakan Kelas Untuk Guru, 343.

Zainuddin Atsani, L. G. M. (2020). Transformasi media pembelajaran pada masa pandemi Covid-19 (Transformation of learning media during Covid-19 pandemic). Al-Hikmah: Jurnal Studi Islam, 1(1), 82-93. http://ejournal.kopertais4.or.id/sasambo/index.php/alhikmah/article/view/3905 